\title{
Prophylactic HPV Vaccines and Prevention of Cervical Intraepithelial Neoplasia
}

\author{
Erica R. Heitmann • Diane M. Harper
}

Published online: 13 July 2012

(C) Springer Science+Business Media, LLC 2012

\begin{abstract}
Cervical cancer kills women of all ages. The irrefutable link to oncogenic human papillomavirus (HPV), a sexually transmitted infection, forever changed society's attitude toward cervical cancer. The advent of HPV vaccines has brought the link of sexual practices and personal behavior to the forefront. The vaccines were aggressively marketed to parents, young girls, public health officials, physicians, and all payor sources before the scientific data defining their actual benefit could be delineated. At this early time, the HPV vaccines prevent persistent type-specific HPV infections, some abnormal Pap tests, some colposcopies, and some excisional procedures in women who are HPV-DNA negative before vaccination. Health-modeling exercises have demonstrated that duration of vaccine efficacy is the most important parameter for any long-term cancer prevention benefit. Implementation efforts have demonstrated that a three-dose series is difficult to achieve and results in a high vaccine wastage rate.
\end{abstract}

Keywords Human papillomavirus · HPV · Vaccines · Cervical intraepithelial neoplasia $\cdot$ Duration of efficacy · Immunogenicity $\cdot$ Colposcopy $\cdot$ Loop electrical excisional procedure $\cdot$ LEEP

\section{E. R. Heitmann}

Department of Obstetrics and Gynecology, Maternal Fetal

Medicine, Department of Biomedical and Health Informatics,

University of Missouri Kansas City School of Medicine,

Truman Medical Center Hospital Hill,

2301 Holmes Street,

Kansas City, MO 64108, USA

D. M. Harper $(\square)$

Gynecologic Cancer Prevention Research Group, Center of Excellence Women's Health, University of Missouri Kansas City

School of Medicine, Truman Medical Center Lakewood,

7900 Lee's Summit Road,

Kansas City, MO 64139, USA

e-mail: Diane.M.Harper@gmail.com

\section{Introduction}

Human papillomavirus (HPV) infection targets epithelial basal cells; hence, all HPV-associated diseases have an epithelial origin, are spread via skin-to-skin contact, and are not viremic. The HPV types associated with human cancers are found within the alpha genus of papillomavirus infections. The phylogenetically related HPV types are clinically focused within species 9 and species 7 . Species 9 includes HPV 16, 31, 33, 35, 52, 58, and 67. Species 7 includes HPV 18, 45, 39, 70, 59, 68, and c85 [1]. Cervical cancer is the most common HPV-associated cancer, making up $5 \%$ of all cancers globally with $100 \% \mathrm{HPV}$ attribution [2].

In countries without routine cervical cancer surveillance programs, the incidence of cervical cancer ranges from 50 to $90 / 100,000$ women. Among countries with opportunistic or organized cervical cancer screening, the incidence is 5-8/100,000 women: 5/100,000 in Finland and 8/100,000 in the United States, Canada, and Western Europe [3]. Routine cytology screening has accomplished this decrease in cervical cancer incidence over the past 70 years. Regardless of conventional or liquid cytology methods, analysis of cellular morphology cannot bring the cervical cancer incidence any lower than $2-3 / 100,000$ due to false-negative and false-positive testing [4].

Adenocarcinomas constitute about a quarter of all cervical cancers and occur at younger ages than the squamous cell cervical cancers. Adenocarcinoma is very difficult to detect at screening and work up, often with later stages of cancer present at diagnosis resulting in significantly higher mortality rates $[5,6]$.

Other HPV-associated cancers with lesser HPV attribution are vulvar $(50 \%)$, vaginal $(90 \%)$, penile $(50 \%)$, anal (80\%), and oropharyngeal (15-80\%) cancers, most of which occur at a younger age and with a better prognosis 
because of the HPV association [2, 7]. Benign HPVassociated lesions include genital warts and respiratory papillomatosis, both of which are orders of magnitude less common in incidence than abnormal cervical cytology due to HPV infection $[8,9]$. While these benign and malignant diseases are germane, public health relevance centers on the fact that $88 \%$ of all HPV-associated diseases are cervical cancer-related and constitute $92 \%$ of all economic costs $[10 \bullet]$.

HPV infections occur throughout a woman's lifetime (Fig. 1) starting in early childhood for some. Infection prevalence peaks between 16 and 25 years of age, drops to a $10 \%$ prevalence until the perimenopausal years, at which time there is an upsurge to near peak prevalences in many populations [11-20]. The concordance of HPV types between male and female partners is low, ranging from 2 to $35 \%$ [21], significantly hindering any attempt to identify the transmission source.

The prevalence of seropositivity for HPV 16/18 infection is independent of any current HPV infection and continues to increase throughout the woman's lifetime [22]. There is no one age at which an entire population is not infected with HPV and no age after which HPV is no longer an infective possibility. Hence, any protection against HPV-associated diseases will have to start very early in life and continue over the expected seven or eight decades of life.

\section{Prevalence of HPV Type by Cervical Status}

HPV infection with oncogenic types occurs without disease sequelae in $90 \%$ of infections [23, 24]. The prevalence of oncogenic HPV infection in women with normal cytology is 5-7 \%. The five most common oncogenic types are HPV $16,18,31,33$, and 45, with HPV 16 and 18 causing half of the infections [25]. About $2.5 \%$ of U.S. women have a lowgrade squamous intraepithelial lesion (LSIL) [8]; LSIL has a $60 \% \mathrm{HPV}$ attribution to HPV 16, 18, 31, 33, and 45 [26]. HPV 16 and 18 infections constitute $27 \%$ and $9 \%$ of women with LSIL cytology, respectively. The low-risk types of HPV, including types 6 and 11, are detected in about $15 \%$ of LSIL cytologies [27] and never progress to a precancerous lesion.

All high-grade squamous intraepithelial lesions (HSIL) are caused by oncogenic HPV infections. HPV 16, 18, 31, 33 , and 45 occur in frequency distributions more closely related to squamous cell cancer than in LSIL cytologies: $45 \%, 7 \%, 9 \%, 7 \%$, and $2 \%$, respectively [28]. The frequency distribution for HPV types associated with squamous cell carcinoma of the cervix around the world is HPV 16 (62 \%), HPV 18 (8\%), HPV 45 (6\%), HPV 31 (5\%), and HVP 33 (4\%) [19]. HPV 58 and 52 replace HPV 31 and 45 in Asian populations at similar distribution frequencies. Adenocarcinoma of the cervix, on the other hand, while also
Fig. 1 HPV prevalence by age. High-risk HPV prevalence exists at all ages, with varying amounts of increase in the perimenopausal age groups [11-19] HPV human papilloma virus

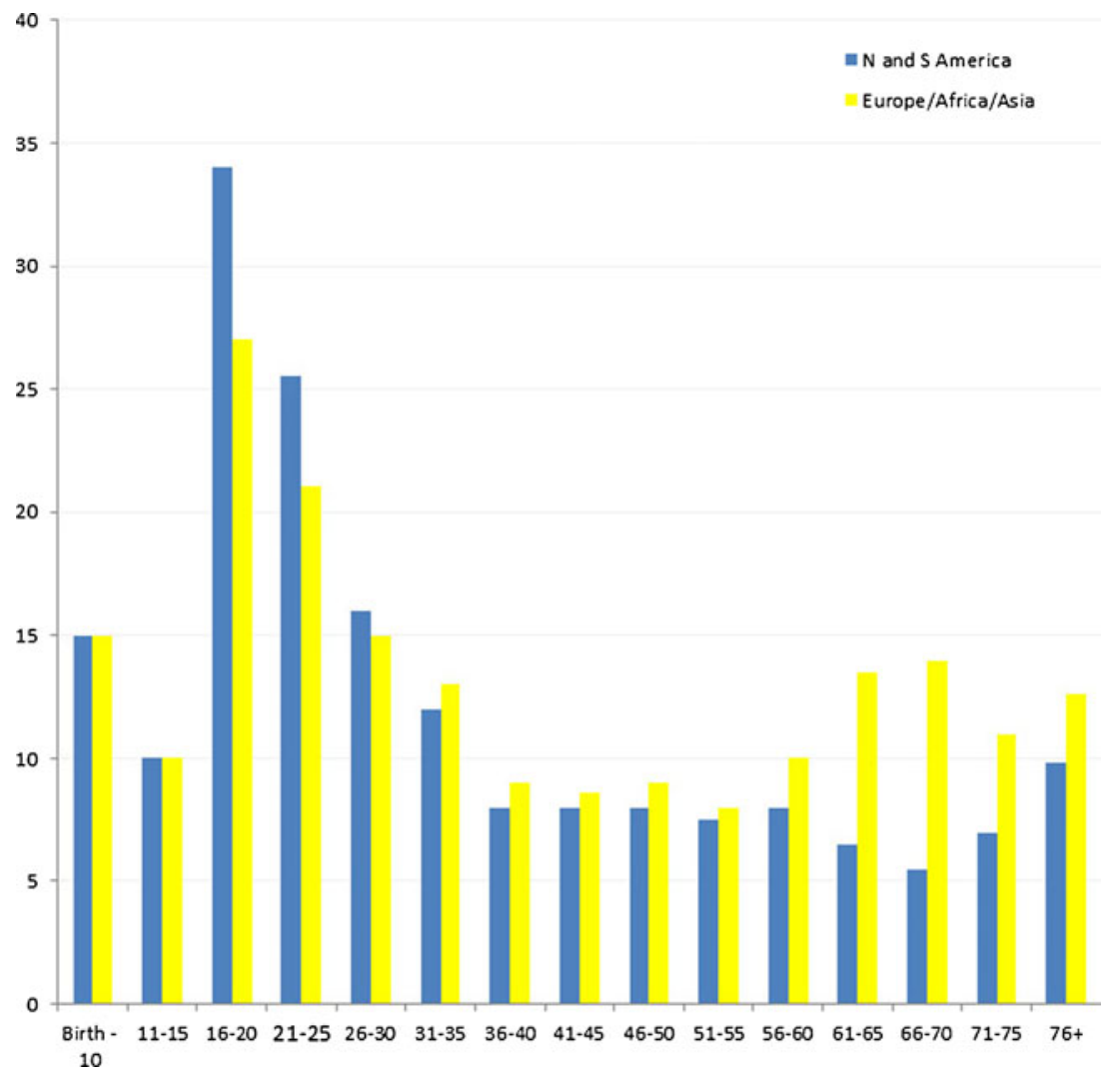


always associated with HPV infection, is attributed to a different distributional frequency of oncogenic types. HPV 16,18 , and 45 constitute nearly $90 \%$ of all adenocarcinomas in all parts of the world [19].

\section{Natural History of HPV Infections}

HPV is an 8000-base pair circular double-stranded DNA virus that is encapsulated by a protein coat made up of L1 and L2 proteins. All HPV infection must occur at the level of the basement membrane; hence, destructive trauma removing parts of the entire stratified epithelium must occur before HPV infection can take place. In response to the wound, basal epithelial cells rapidly spread laterally to repair the wound. Infection into these basal cells is processed by two sets of receptors. The first receptor, a heparin sulfate proteoglycan, is on the basement membrane and binds to the outer L1 protein coat of the HPV virion (Fig. 2) [29]. This binding causes a transformational change in the outer protein coat allowing the $\mathrm{L} 2$ proteins to be exposed through the L1 layer. A protease convertase enzyme (eg, furin) cleaves part of the L2 protein exposing the neutralizing L2 epitope, but more importantly exposing a previously unexposed region of the L1 protein. This newly exposed L1 region binds to the cell receptor on the basal epithelial cell causing

a

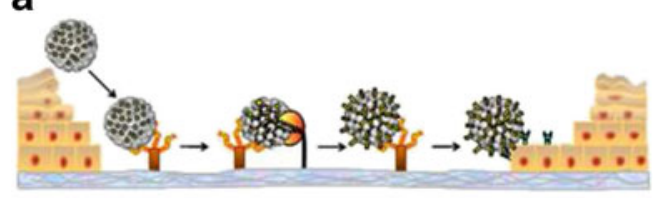

b

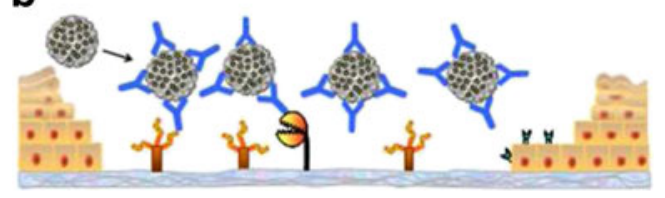

C

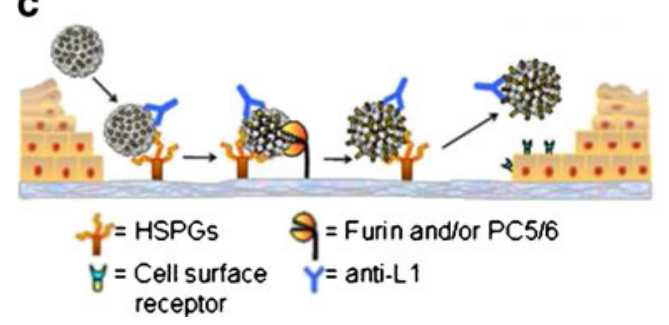

Fig. 2 HPV infection of epithelial basal cells and antibody function. HPV infection occurs via two separate receptor mediations. High antibody titers prevent interaction with the basement membrane receptor. Low antibody titers can only prevent interaction if there is high avidity [29]. HPV human papilloma virus; HSPGs heparan sulfate proteoglycans (From Day et al. [29], with permission.) episomal internalization of the double-stranded DNA into the human epithelial cell nucleus.

Most HPV infections are not recognized by the immune system for many reasons. During HPV replication, there are no double-stranded RNA intermediates to invoke innate immune responses. The proteins that are synthesized during HPV replication are dependent on the level of epithelial stratification; hence, low concentrations of early nonstructural proteins (eg, E4, E6, and E7) in the nuclei of the parabasal and intermediate cells are not detected by the Langerhans' or dendritic cells. The entire process of HPV replication occurs within epithelial stratification and does not invoke cytolysis. There are no cytokines or antigens released to invoke innate immunity responses; there is no viremic phase of infection; there is little systemic antigen presentation and, hence, little opportunity for immune memory to be reactivated at a future infection $[30,31]$.

Natural history studies of HPV infection show that $70 \%$ of HPV infections are no longer detectable after 1 year and $90 \%$ are no longer detectable at 2 years. Only $5 \%$ of infections progress to a cervical intraepithelial neoplasia (CIN) grade 2 or 3 precancerous stage within 3 years. Of those CIN 3 lesions that do not regress, only $20 \%$ progress to invasive carcinoma within 5 years, and only $40 \%$ progress to invasive carcinoma within 30 years (Fig. 3) [23]. At this time, there is no technology to predict which of the CIN 3 lesions will progress and which will just persist.

\section{Clinical Value of Prophylactic HPV Vaccines}

While cervical cancer prevention is a noble goal, there is insufficient knowledge about duration of protection of the current HPV vaccines to state that there will be either personal or population benefit in direct cancer prevention due to their use. The most effective method for preventing cervical cancer continues to be cervical cytology or HPV testing used in a routine organized system. The only clinical value prophylactic HPV vaccines have at this time is the prevention of type-specific HPV infections, the reduction in numbers of abnormal screening cytologies, the reduction in numbers of colposcopies and biopsies needed for diagnostic follow-up of abnormal cytology screens, and a reduction in the number of excisional treatments necessary to remove the CIN 2/3 lesion detected. Table 1 shows the phase 3 data for both Cervarix (GlaxoSmithKline, London, U.K.) and Gardasil (Merck \& Co., Whitehouse Station, N.J.) randomized controlled trials measured at 3.6 years. While there are differences in the level of prevention afforded by each vaccine, both vaccines show a modest reduction in overall abnormal cytology resulting in a reduction of excisional therapies. This benefit is real and will produce quality-of- 

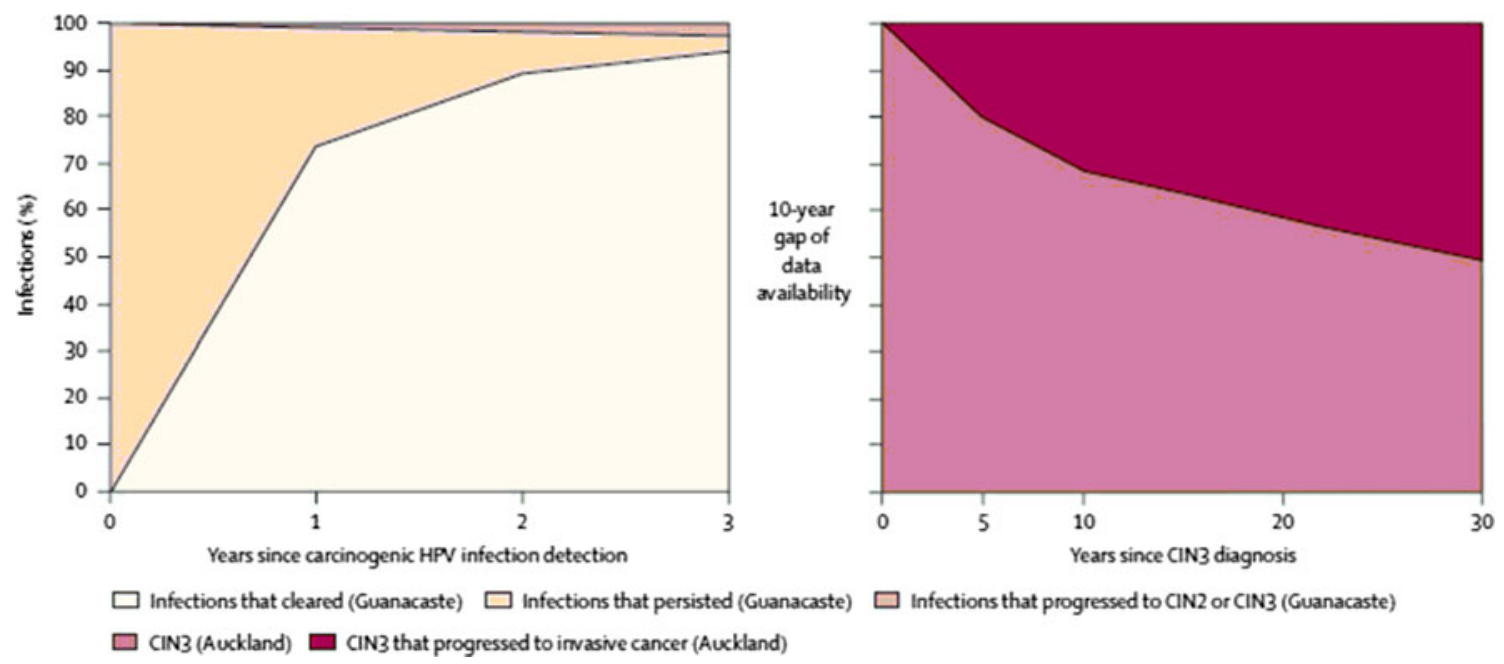

Fig. $3 \mathrm{HPV}$ persistence and progression. Within 3 years, $5 \%$ of HPV infections progress to CIN 2/3; $20 \%$ of CIN 3 progresses to cancer within 5 years; and $40 \%$ of CIN 3 progresses to cancer within 30 years

life gains for women who chose to be vaccinated at a time that is within 3.5 years of their maximal sexual activity. Phase 2 trial data extend the duration of vaccine efficacy to 5 years for Gardasil and 9.4 years for Cervarix [32, 33•].

\section{Prevention of HPV Type-Specific Persistent Infection and Intraepithelial Neoplasias}

Both HPV prophylactic vaccines prevent vaccine-relevant type-specific persistent infections. Both prophylactic vaccines were studied for almost 4 years in the large phase 3 trials used for regulatory approval. Through phase 2 trials, smaller populations were studied for a longer time period. Gardasil prevents HPV 6/11/16/18 persistent infections for 5 years at a $96 \%$ efficacy $(95 \%$ CI of 83, 100) [32]. Cervarix prevents HPV 16/18 persistent infections for 9.4 years at a $100 \%$ efficacy $(95 \%$ CI of 84,100$)$ [33•]. Cervarix exhibits intraspecies cross protection showing efficacy against seven of the oncogenic HPV types within species 9 and species 7 of papillomavirus types: HPV 16/ 18/31/33/45/51/52 (Table 2) [34••].

While cervical intraepithelial neoplasia grade 2 (CIN 2) is a recognized histologic misclassification [35], nonetheless, both sets of clinical trials for Cervarix and Gardasil were based on a squamous outcome end point of CIN 2 or CIN 3 related to HPV 16 or 18, as a cancer surrogate. Adenocarcinoma in situ (AIS) was grouped with the precancerous squamous composite end point and denoted as CIN 2+. Table 3 shows that both vaccines offer nearly $100 \%$ efficacies against CIN $2+$ caused by HPV 16 or 18 , with a substantial efficacy of $93 \%$ for Cervarix against CIN 3+ attributed to any HPV type.
[23, 24] $H P V$ human papilloma virus; $C I N$ cervical intraepithelial neoplasia (From Schiffman and Rodríguez [23] with permission.)

\section{Immunogenicity of the HPV Vaccines}

High antibody titers to L1 and low antibody titers with high avidity for L1 can block HPV infection in vitro [29]. Low antibody titers with low avidity may not block HPV infection and antibody avidity for new HPV infections may decrease over time [36].

In vivo, antibody titers were measured by different immunoassays throughout the three phases of the HPV vaccine trials. The pseudovirion neutralization assay (PBNA), developed by the U.S. National Institutes of Health (NIH), is considered the most accurate reflection of the neutralizing ability of the induced antibodies. Proprietary reports of immune responses have used competitive Luminex immunoassay (cLIA [Invitrogen, Grand Island, NY]) in milliMerck units/mL and enzyme-linked immunosorbent assay (ELISA) in ELISA units/mL.

Data from 181 women in the Brazilian cohort of the phase 2 study of Cervarix efficacy show high and sustained antibody titers, measured by PBNA, four times above titers induced by natural infection for both HPV 16 and HPV 18 lasting at least 9.4 years (Figs. 4 and 5) [37]. Cervarixinduced antibody titers for HPV 16 and HPV 18 were detectable in all recipients at the end of the trial with no loss.

Data from the phase 2 study of 114 vaccinated women document Gardasil-induced antibody titers for anti-HPV 6/ $11 / 16 / 18$ for 5 years [32]. Figures $6,7,8$ and 9 show the Gardasil-induced antibody kinetics. The geometric mean titers for HPV 6/11/18 become equivalent to naturally induced titers within the 5-year time frame. More worrisome for Gardasil long-term protection is the inability to detect any anti-HPV 16 and 18 antibodies a short time after the three-dose vaccination series. Figure 10 shows that $14 \%$ of 
Table 1 Clinical value of HPV vaccines: protection unrelated to HPV type $[51,52]$

\begin{tabular}{ll}
\hline TVC-N population $^{*}$ & $\begin{array}{l}\text { Cervarix efficacy [51], \% } \\
(95 \% \text { Confidence Intervals })\end{array}$ \\
\hline ASCUS & $23 \%(17,29)$ \\
LSIL & $24 \%(14,33)$ \\
HSIL & $54 \%(5,79)$ \\
All abnormal cytology & $27 \%(21,33)$ \\
Reduction in colposcopies & $29 \%(22,36)$ \\
Reduction in excisional therapies & $70 \%(58,79)$ \\
& \\
USP-N population ${ }^{* *}$ & Gardasil efficacy [52], \% \\
& $(95 \%$ Confidence Intervals $)$ \\
ASCUS & $22 \%(9,36)$ \\
LSIL & $17 \%(9,24)$ \\
HSIL & $45 \%(4,69)$ \\
All abnormal cytology & $17 \%(10,24)$ \\
Reduction in colposcopies & $20 \%(12,27)$ \\
Reduction in excisional therapies & $42 \%(28,54)$
\end{tabular}

ASCUS atypical squamous cells of undetermined significance; LSIL low-grade squamous intraepithelial lesion; HSIL high-grade squamous intraepithelial lesions

*TVC-N means total vaccinated cohort of naïve women who are 15 25 years old at baseline; had normal cytology and were seronegative for HPV 16, 18 at baseline; were DNA-negative for 14 oncogenic HPV types at baseline $(16,18,31.33,35,39,45,51,52,56,58,59,66$, and 68); had received at least one injection; had at least one follow-up datum; case counting started first day after first injection; and patients were followed for an average of 43.7 months [51]

**USP-N means unrestricted susceptible population of women 1626 years old at baseline who had normal cytology and were seronegative and DNA-negative for HPV 6, 11, 16, 18; were DNA negative, regardless of serostatus, for $31,33,35,39,45,51,52,56,58$, and 59; had received at least one injection; had at least one follow-up datum; case counting started first day after first injection; and patients were followed for a mean of 43.2 months [52]

Table 2 Cervarix efficacy against persistent infection for HPV types in addition to HPV 16/18 [34]

\begin{tabular}{ll}
\hline TVC-N Population* & $\begin{array}{l}\text { Cervarix efficacy [51], \% } \\
(95 \% \text { Confidence Intervals) }\end{array}$ \\
\hline HPV 31 & $77 \%(67,84)$ \\
HPV 33 & $43 \%(19,60)$ \\
HPV 45 & $79 \%(61,89)$ \\
HPV 51 & $26 \%(12,37)$ \\
HPV 52 & $19 \%(3,32)$
\end{tabular}

*TVC-N means total vaccinated cohort of naïve women who are 1525 years old at baseline; had normal cytology and were seronegative for HPV 16, 18 at baseline; were DNA-negative for 14 oncogenic HPV types at baseline $(16,18,31.33,35,39,45,51,52,56,58,59,66$, and 68); had received at least one injection; had at least one follow up datum; case counting started first day after first injection; and patients were followed for an average of 43.7 months [34]
Table 3 HPV Vaccine efficacy for 3.6 years from phase 3 trials [51, 52]

\begin{tabular}{ll}
\hline TVC-N population & $\begin{array}{l}\text { Cervarix efficacy [51], } \% \\
\text { (95\% Confidence Intervals) }\end{array}$ \\
\hline CIN $2+$ by HPV 16/18 & $95 \%(88,98)$ \\
CIN $2+$ by any HPV & $65 \%(53,74)$ \\
CIN 3+ by HPV 16/18 & $92 \%(67,99)$ \\
CIN 3+ by any HPV & $93 \%(79,99)$ \\
AIS by HPV 16/18 & $100 \%(16,100)$ \\
& \\
NPS Population ${ }^{* *}$ & Gardasil efficacy [52], \% \\
CIN 2+ by HPV 16/18 & $105 \%$ Confidence Intervals) \\
CIN 2+ by any HPV & $43 \%(24,57)$ \\
CIN 3+ by HPV 16/18 & $100 \%(91,100)$ \\
CIN 3+ by any HPV & $43 \%(13,63)$ \\
AIS by HPV 16/18 & $60 \%(\mathrm{NS})$ \\
\hline
\end{tabular}

CIN cervical intraepithelial neoplasia; $A I S$ adenocarcinoma in situ; $N S$ not significant

*TVC-N means total vaccinated cohort of naïve women who are 1525 years old at baseline; had normal cytology and were seronegative for HPV 16, 18 at baseline; were DNA-negative for 14 oncogenic HPV types at baseline $(16,18,31.33,35,39,45,51,52,56,58,59,66$, and 68); had received at least one injection; had at least one follow up datum; case counting started first day after first injection; and patients were followed for an average of 43.7 months [51]

**NPS means naïve population simulation. This population was restricted to patients who received at least one injection of HPV6/11/16/ 18 vaccine or placebo and had follow-up, and, at enrollment, were seronegative and DNA negative to HPV6, 11, 16, and 18; were DNA negative to the 10 nonvaccine types, including HPV31, 33, 35, 39, 45, 51, 52, 56, 58, and 59; and had a normal Papanicolaou test result. Patients were followed for a mean of 43.2 months [52]

women lose all detectable anti-HPV 16 antibodies within 8.5 years after three doses of the monovalent HPV 16 prototype Gardasil vaccine [38], while $35 \%$ of women lose all detectable anti-HPV 18 antibodies within 5 years after three doses of the quadrivalent Gardasil vaccine [39].

There appears to be a time-dependent relationship with the loss of anti-HPV 18 antibodies titers that could extrapolate to complete loss of prevention against HPV 18 long before there is an opportunity to prevent any HPV 18 cervical cancers. Low antibody titers to HPV 6 and 11, as well as a $10 \%$ loss of seroconversion within 5 years, may lead to a time-limited genital wart protection. This may be seen in Australia, which has reported a genital wart prevalence reduction initially after Gardasil vaccination [40], if the antibody response is insufficient for long-term protection.

Supporting the lack of duration of Gardasil-induced immune response is the lack of detection of any HPV 18 antibodies in $38 \%$ of men within 2 years of vaccination (Fig. 11). All men had initially seroconverted after the three dose vaccination series, but went on to lose detectable antibodies for HPV 6/11/18 in a very short time interval [41]. Specifically, 


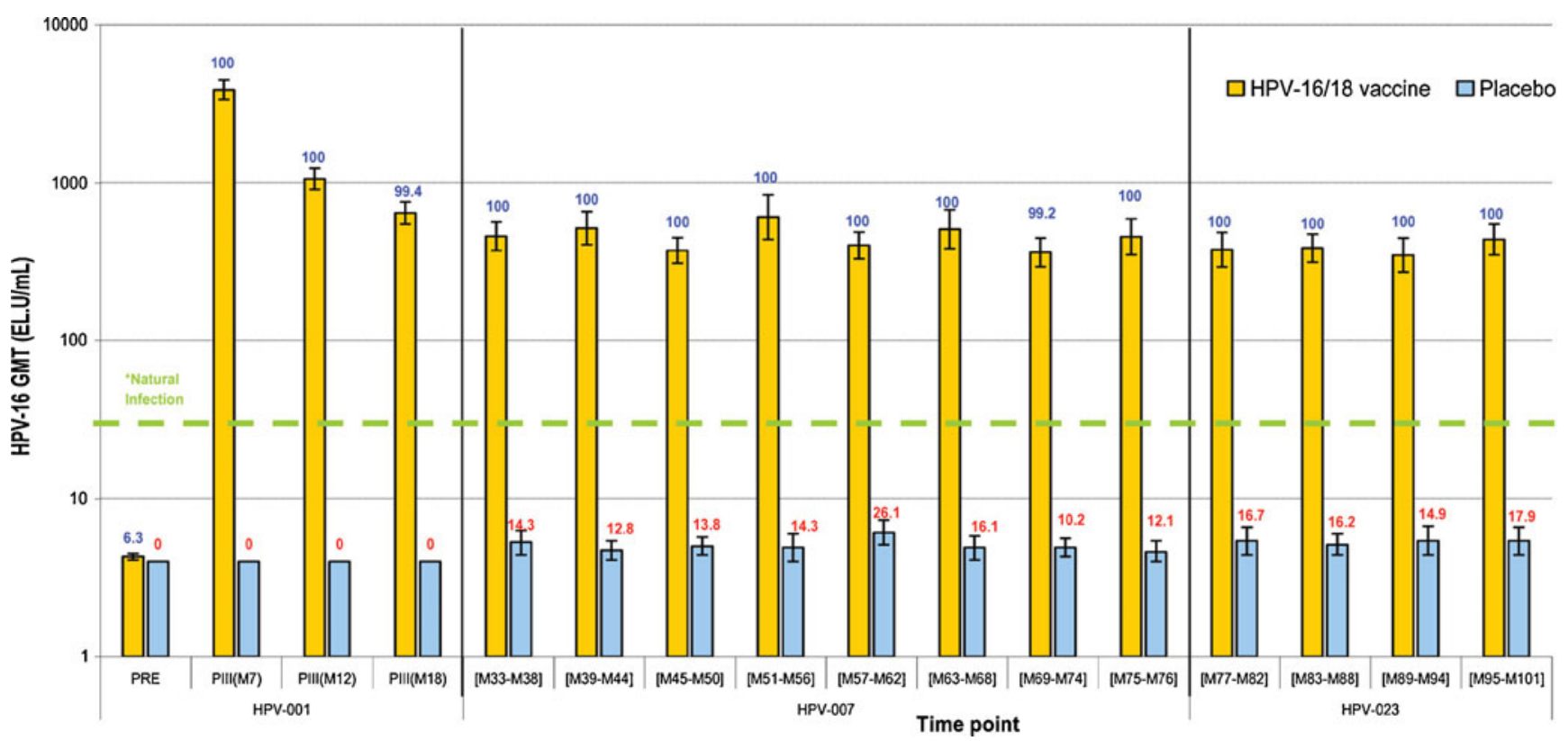

Fig. 4 Cervarix anti-HPV-16 titers last for at least 9.4 years $(n=181)$. PBNA neutralizing antibody titers for the Brazilian women continuing in the 9.4-year study stay at least four times above the titer induced by

the men lost all detectable antibodies to HPV 6 and HPV 11 one to 3 years earlier than did a similar proportion of women.

\section{Vaccine Implementation}

Both HPV vaccines exhibit efficacy when used in a threedose regimen. Regulatory approval by the U.S. Food and natural infection [37] $H P V$ human papilloma virus; $P B N A$ pseudovirion-based neutralization assay (From Roteli-Martins et al. [37], with permission.)

Drug Administration (FDA), European Medicines Agency (EMEA), and other international bodies was based on this three-dose data. Clinical practice often does not reflect the rigor of randomized controlled trials, though. Experience in the United States shows that while $\$ 1.4$ billion was spent in 2008 on Gardasil vaccinations by the Centers for Disease Control and Prevention as well as private insurances, over $60 \%$ of those who received Gardasil received

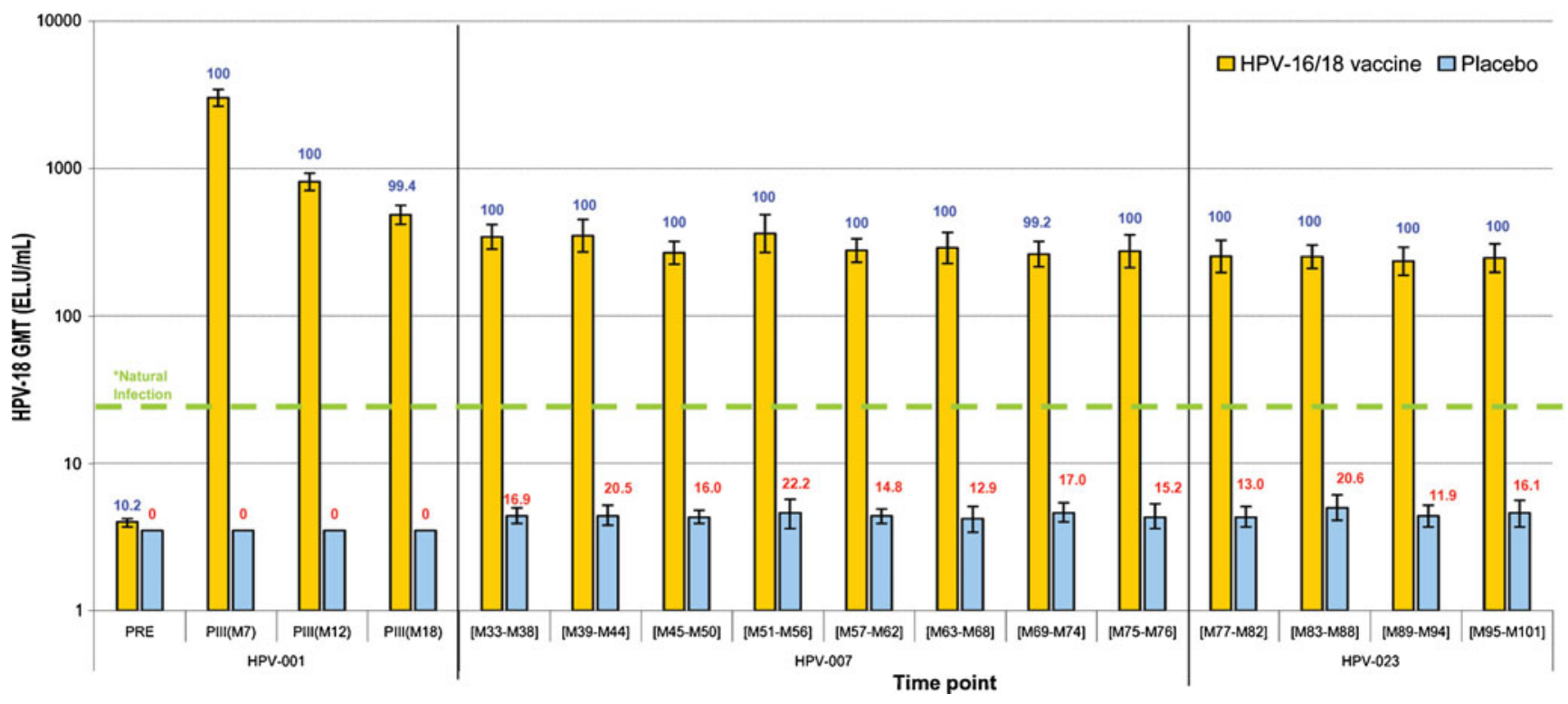

Fig. 5 Cervarix anti-HPV-18 titers last for at least 9.4 years $(n=181)$. PBNA neutralizing antibody titers for the Brazilian women continuing in the 9.4-year study stay at least four times above the titer induced by natural infection [37] $H P V$ human papilloma virus; $P B N A$ pseudovirion-based neutralization assay (From Roteli-Martins et al. [37], with permission.) 


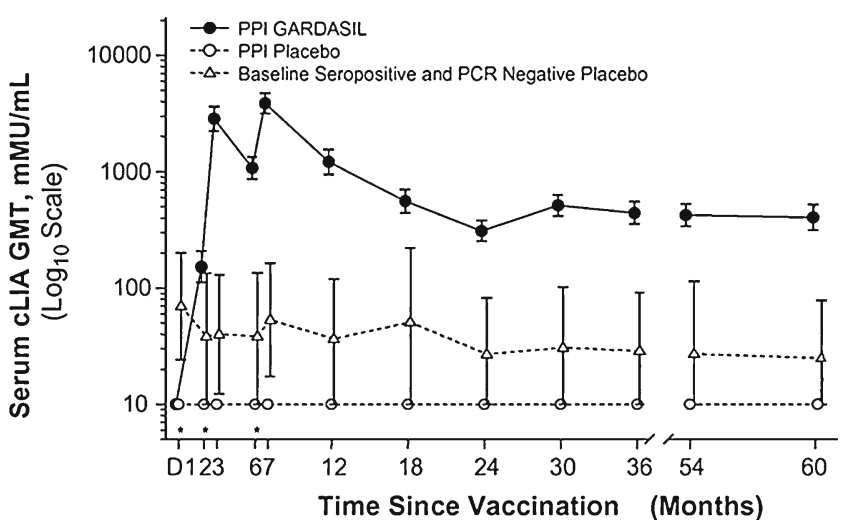

Fig. 6 Gardasil anti-HPV-16 titers over 5 years $(n=78)$. Gardasilinduced anti-HPV-16 titers remain tenfold higher than titers induced by natural infection for 5 years $H P V$ human papilloma virus; $c L I A$ chemiluminescent immunoassay; GMT geometric mean titers; $P P I$ perprotocol immunogenicity; $P C R$ polymerase chain reaction (From Olsson et al. [39], with permission.)

less than three doses or three doses at ineffective timing intervals [42]. This significant wastage could be avoided in the future if prophylactic HPV vaccines requiring less than three doses are implemented.

A Cervarix randomized controlled trial of women 1826 years old resulted in 384 women receiving only one dose. Vaccine efficacy of one dose after at least 4 years was $100 \%$ against 12-month persistent HPV 16/18 infection [43••]. The study population was HPV 16/18 DNA negative at baseline regardless of serostatus and regardless of entry cytology. A one-dose implementation product would reduce the wastage that occurs when women do not complete the three-dose series in a timely manner. This option has to be a high priority for regulatory approval because the World Health Organization (WHO) and the Pan American Health

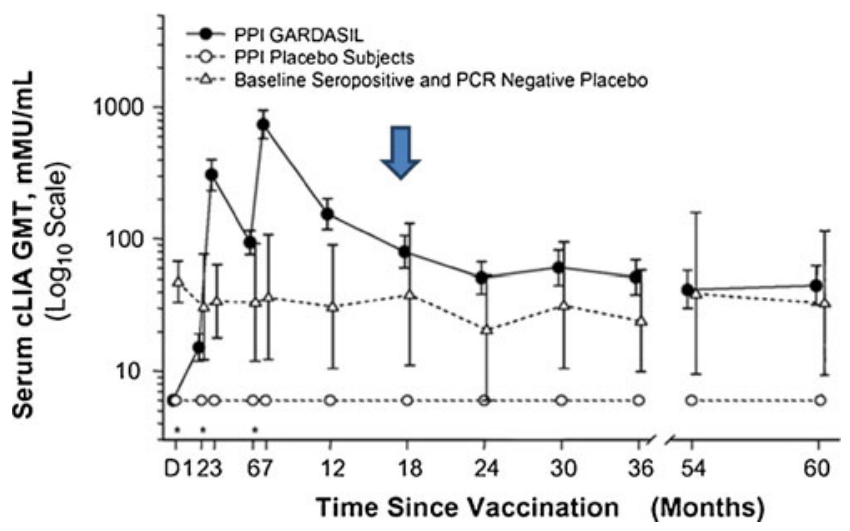

Fig. 7 Gardasil anti-HPV-18 titers over 5 years $(n=82)$. Gardasilinduced anti-HPV-18 titers over 5 years. Arrow indicates time point at which induced antibody titers are no different from antibody titers induced by natural infection [32] HPV human papilloma virus; $c L I A$ chemiluminescent immunoassay; GMT geometric mean titers; $P P I$ perprotocol immunogenicity; $P C R$ polymerase chain reaction (From Olsson et al. [39], with permission.)

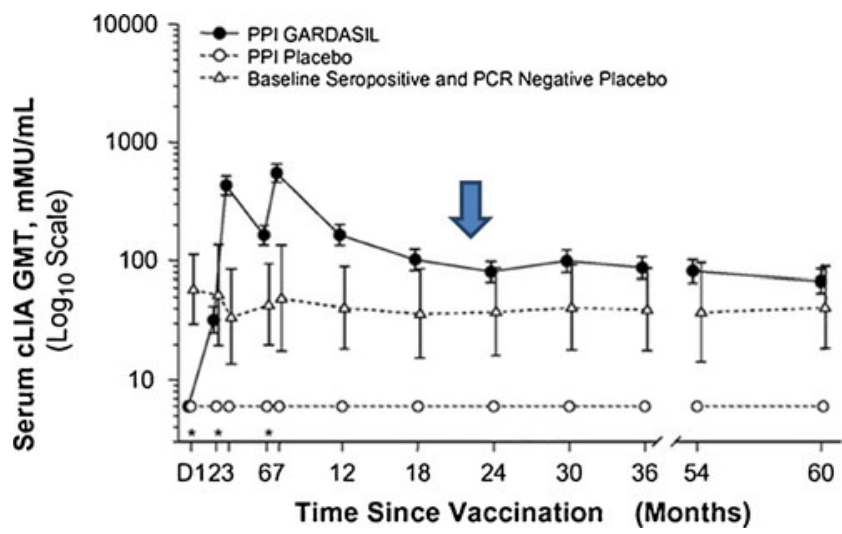

Fig. 8 Gardasil induced anti-HPV-6 titers over 5 years. Arrow indicates time point at which induced antibody titers are no different from antibody titers induced by natural infection [32] $H P V$ human papilloma virus; cLIA chemiluminescent immunoassay; GMT geometric mean titers; $P P I$ per-protocol immunogenicity; $P C R$ polymerase chain reaction (From Olsson et al. [39], with permission.)

Organization (PAHO) cannot implement a one-dose program without appropriate regulatory approvals.

\section{Duration of Vaccine Efficacy}

Prevention of persistent HPV infection is the mechanism of action of these vaccines. Should enough persistent HPV infection be prevented, then subsequent type-specific disease development may be prevented as well. While $70 \%$ of HPV infections are cleared at a year, and $90 \%$ are cleared by 2 years via natural immune mechanisms, the efficacy of the vaccines must be sufficiently broad to prevent the $5 \%$ of persistent infections from developing into CIN 3, the recognized cancer precursor. Modeling exercises show that no

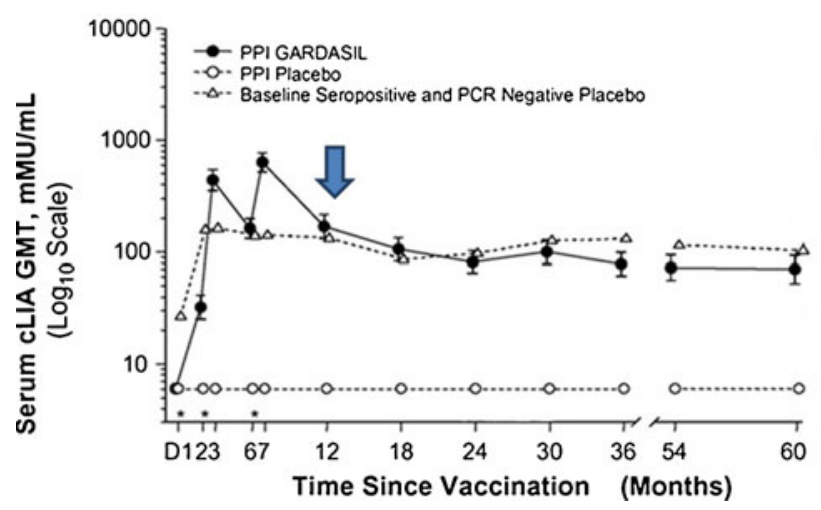

Fig. 9 Gardasil anti-HPV-11 titers over 5 years $(n=83)$. Gardasilinduced anti-HPV 11 titers over 5 years. Arrow indicates time point at which induced antibody titers are no different from antibody titers induced by natural infection [32] HPV human papilloma virus; cLIA chemiluminescent immunoassay; GMT geometric mean titers; $P P I$ perprotocol immunogenicity; PCR polymerase chain reaction (From Olsson et al. [39], with permission.) 
Fig. 10 Percentage of females (15-24 years) who lose Gardasil-induced antibody titers over time. Substantial proportions of women no longer have detectable antibody titers to vaccine relevant typespecific oncogenic HPV types after 5 years $[38,39] H P V$ human papilloma virus

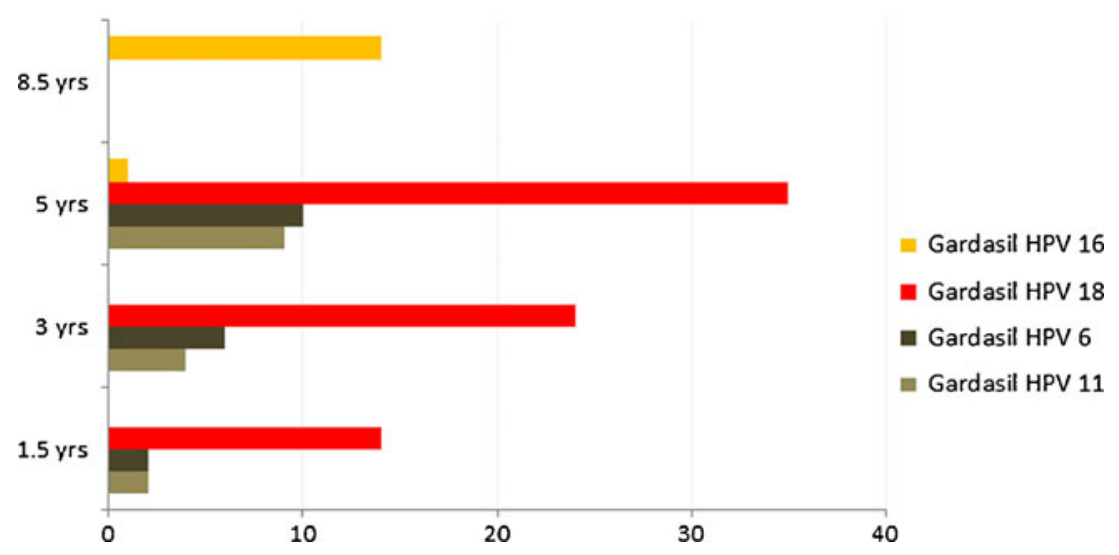

reduction in cervical cancer will occur if the vaccines do not offer at least 15 years of at least $90 \%$ efficacy against at least HPV 16 [44]. If less protection is achieved, women will continue to be infected with HPV, only at a later point in time, going on to develop cervical cancer should she not have access to screening programs.

\section{Conclusions}

The prevention of cervical cancer is dependent on many factors: time the screening program has been in place, compliance, willingness, economics, politics, access, implementation, efficacy, and duration of efficacy to name the most prominent. The program of repeated routine cervical screening in industrialized countries has taken 70 years to reach levels of reduced cervical cancer incidence of 5-8/100,000
$[45,46]$, still with significant pockets of populations not being routinely screened. If HPV vaccination alone is used as a cervical cancer prevention program, the lowest incidence Gardasil could provide would be 14/100,000 and Cervarix, due to its cross protection, would be $9.5 / 100,000$ [47]. These results would be expected after 60 years of $100 \%$ efficacy, $100 \%$ population coverage, and no need for boosters due to lifetime duration of efficacy [48]. Even with the newer Gardasil formulation with five more oncogenic types added, the lowest incidence of cervical cancer it could achieve would be 9.3/100,000 assuming the same $100 \%$ efficacy, $100 \%$ population coverage and lifetime duration after three appropriately timed doses.

At this time, prophylactic HPV vaccination cannot eradicate cervical cancer. Neither can organized screening programs. The combination of early in life vaccination with the current prophylactic HPV vaccines followed by organized
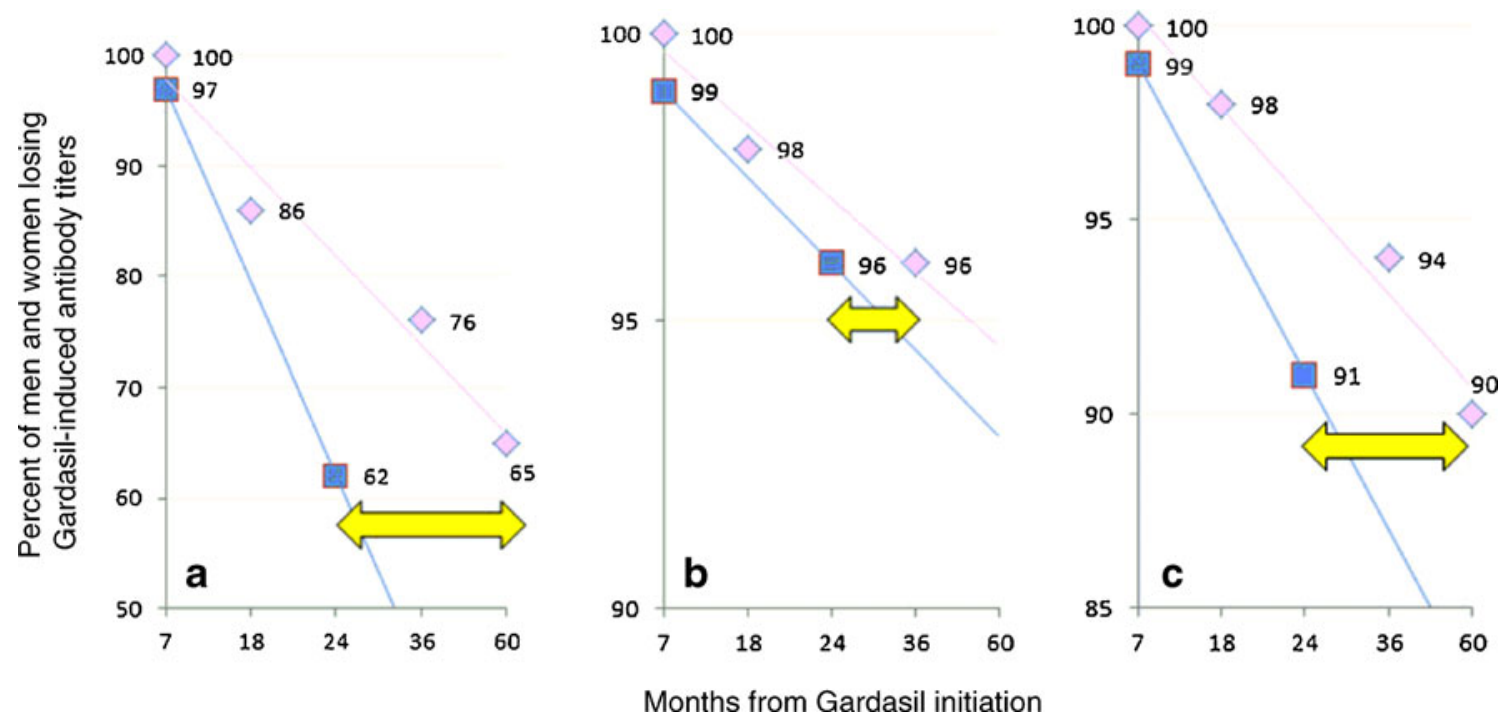

Fig. 11 Percentage loss of Gardasil-induced antibody titers over time in men compared with women of the same age ranges. a HPV 18: Nearly $40 \%$ of men lose all detectable antibodies to HPV 18 within 2 years of the complete vaccination series. b HPV 11 : Nearly $5 \%$ of men lose all detectable HPV 11 antibodies within 2 years of the complete vaccination series. c HPV 6: Nearly $10 \%$ of males lose all detectable antibody titers to HPV 6 within 2 years of the complete vaccination series. $H P V$ human papilloma virus 
screening in the third and subsequent decades of life may, over 60 years, provide an incremental decrease in the incidence of cervical cancer by $1-2 / 100,000$ women. This will only be true if the duration of vaccine efficacy is at least 15 years.

Rather than spend billions in prophylactic vaccination of all women, a wiser strategy may be to spend resources on therapeutic vaccine development that is independent of HPV type for the relatively small number of women who develop CIN 3 lesions. Prophylactic vaccination of all women cannot be a wise investment until we have a one dose regimen that has lifetime efficacy or a minimum number of one dose boosters. Routine screening must continue. Without vaccine efficacy being lifetime in duration, countries without cervical cancer screening programs will benefit most from the development of routine screening programs that range from one to seven times in a lifetime [49], not mandated population vaccination.

Acknowledgements The authors would like to thank Gwen E. Sprague for her assistance in completing this manuscript.

Disclosures E. R. Heitmann: none. Dr. Diane M. Harper has received honoraria for speaking and for participation on advisory boards from Merck and GlaxoSmithKline. The institutions at which DMH has conducted HPV vaccine trials have received funding to support clinical trials on the vaccines discussed herein from Merck \& Co. and GlaxoSmithKline, Inc.

\section{References}

Papers of particular interest, published recently, have been highlighted as:

- Of importance

•- Of major importance

1. de Villiers EM, Fauquet C, Broker TR, Bernard HU, zur Hausen H. Classification of papillomaviruses. Virology. 2004;324(1):17-27.

2. Ferlay J, Shin HR, Bray F, Forman D, Mathers C, Parkin DM. Estimates of worldwide burden of cancer in 2008: GLOBOCAN 2008. Int J Cancer. 2010;127(12):2893-917.

3. WHO/ICO HPV Information Centre. Accessed May 1, 2012. http://apps.who.int/hpvcentre/statistics/dynamic/ico/country_pdf/ XWX.pdf?CFID $=5990732 \&$ CFTOKEN $=70132897$

4. Sawaya GF, Grimes DA. New technologies in cervical cytology screening: a word of caution. Obstet Gynecol. 1999;94(2):307-10.

5. Smith HO, Tiffany MF, Qualls CR, Key CR. The rising incidence of adenocarcinoma relative to squamous cell carcinoma of the uterine cervix in the United States-a 24-year population-based study. Gynecol Oncol. 2000;78(2):97-105.

6. Gunnell AS, Ylitalo N, Sandin S, Sparén P, Adami HO, Ripatti S. A longitudinal Swedish study on screening for squamous cell carcinoma and adenocarcinoma: evidence of effectiveness and overtreatment. Cancer Epidemiol Biomarkers Prev. 2007;16(12):2641-8.

7. Chaturvedi AK, Engels EA, Pfeiffer RM, Hernandez BY, Xiao W, Kim E, Jiang B, Goodman MT, Sibug-Saber M, Cozen W, Liu L, Lynch CF, Wentzensen N, Jordan RC, Altekruse S, Anderson WF, Rosenberg PS, Gillison ML. Human papillomavirus and rising oropharyngeal cancer incidence in the United States. J Clin Oncol. 2011;29(32):4294-301.

8. Eversole GM, Moriarty AT, Schwartz MR, Clayton AC, Souers R, Fatheree LA, Chmara BA, Tench WD, Henry MR, Wilbur DC. Practices of participants in the college of american pathologists interlaboratory comparison program in cervicovaginal cytology, 2006. Arch Pathol Lab Med. 2010;134(3):331-5.

9. Campisi P, Hawkes M, Simpson K, Canadian Juvenile Onset Recurrent Respiratory Papillomatosis Working Group. The epidemiology of juvenile onset recurrent respiratory papillomatosis derived from a population level national database. Laryngoscope. 2010;120(6):1233-45.

10. - Myers ER. The economic impact of HPV vaccines: not just cervical cancer. Am J Obstet Gynecol. 2008;198(5):487-8. This article details the costs associated with HPV diseases showing that cervical cancer early detection and prevention comprises nearly all of the economic costs of HPV-associated diseases in the United States.

11. Cubie HA, Plumstead M, Zhang W, de Jesus O, Duncan LA, Stanley MA. Presence of antibodies to human papillomavirus virus-like particles (VLPs) in 11-13-year-old schoolgirls. J Med Virol. 1998;56(3):210-6.

12. Schiffman M, Kjaer SK. Chapter 2: Natural history of anogenital human papillomavirus infection and neoplasia. J Natl Cancer Inst Monogr. 2003;31:14-9.

13. Rintala MA, Grénman SE, Järvenkylä ME, Syrjänen KJ, Syrjänen SM. High-risk types of human papillomavirus (HPV) DNA in oral and genital mucosa of infants during their first 3 years of life: experience from the Finnish HPV Family Study. Clin Infect Dis. 2005;41(12):1728-33.

14. Smith EM, Johnson SR, Ritchie JM, Feddersen D, Wang D, Turek LP, Haugen TH. Persistent HPV infection in postmenopausal age women. Int J Gynaecol Obstet. 2004;87(2):131-7.

15. Smith EM, Ritchie JM, Yankowitz J, Swarnavel S, Wang D, Haugen TH, Turek LP. Human papillomavirus prevalence and types in newborns and parents: concordance and modes of transmission. Sex Transm Dis. 2004;31(1):57-62.

16. Bandyopadhyay S, Sen S, Majumdar L, Chatterjee R. Human papillomavirus infection among Indian mothers and their infants. Asian Pac J Cancer Prev. 2003;4(3):179-84.

17. Stone KM, Karem KL, Sternberg MR, McQuillan GM, Poon AD, Unger ER, Reeves WC. Seroprevalence of human papillomavirus type 16 infection in the United States. J Infect Dis. 2002;186 (10): $1396-402$.

18. Dunne EF, Karem KL, Sternberg MR, Stone KM, Unger ER, Reeves WC, Markowitz LE. Seroprevalence of human papillomavirus type 16 in children. J Infect Dis. 2005;191(11):1817-9.

19. de Sanjosé S, Diaz M, Castellsagué X, Clifford G, Bruni L, Muñoz N, Bosch FX. Worldwide prevalence and genotype distribution of cervical human papillomavirus DNA in women with normal cytology: a meta-analysis. Lancet Infect Dis. 2007;7(7):453-9.

20. Bruni L, Diaz M, Castellsagué X, Ferrer E, Bosch FX, de Sanjosé S. Cervical human papillomavirus prevalence in 5 continents: meta-analysis of 1 million women with normal cytological findings. J Infect Dis. 2010;202(12):1789-99.

21. Burchell AN, Winer RL, de Sanjosé S, Franco EL. Chapter 6: Epidemiology and transmission dynamics of genital HPV infection. Vaccine. 2006;24 Suppl 3:S3/52-61.

22. Vaccarella S, Franceschi S, Clifford GM, Touzé A, Hsu CC, de Sanjosé S, Pham TH, Nguyen TH, Matos E, Shin HR, Sukvirach S, Thomas JO, Boursaghin L, Gaitan J, Snijders PJ, Meijer CJ, Muñoz N, Herrero R, Coursaget P, IARC HPV Prevalence Surveys Study Group. Seroprevalence of antibodies against human papillomavirus (HPV) types 16 and 18 in four continents: the International Agency for Research on Cancer HPV Prevalence Surveys. Cancer Epidemiol Biomarkers Prev. 2010;19(9):2379-88. 
23. Schiffman M, Rodríguez AC. Heterogeneity in CIN3 diagnosis. Lancet Oncol. 2008;9(5):404-6.

24. McCredie MR, Sharples KJ, Paul C, Baranyai J, Medley G, Jones RW, Skegg DC. Natural history of cervical neoplasia and risk of invasive cancer in women with cervical intraepithelial neoplasia 3: a retrospective cohort study. Lancet Oncol. 2008;9(5):42534.

25. Clifford GM, Gallus S, Herrero R, Muñoz N, Snijders PJ, Vaccarella S, Anh PT, Ferreccio C, Hieu NT, Matos E, Molano M, Rajkumar R, Ronco G, de Sanjosé S, Shin HR, Sukvirach S, Thomas JO, Tunsakul S, Meijer CJ, Franceschi S, IARC HPV Prevalence Surveys Study Group. Worldwide distribution of human papillomavirus types in cytologically normal women in the International Agency for Research on Cancer HPV prevalence surveys: a pooled analysis. Lancet. 2005;366(9490):991-8.

26. Clifford GM, Rana RK, Franceschi S, Smith JS, Gough G, Pimenta JM. Human papillomavirus genotype distribution in low-grade cervical lesions: comparison by geographic region and with cervical cancer. Cancer Epidemiol Biomarkers Prev. 2005;14(5):115764.

27. Zuna RE, Wang SS, Rosenthal DL, Jeronimo J, Schiffman M, Solomon D, ALTS Group. Determinants of human papillomavirusnegative, low-grade squamous intraepithelial lesions in the atypical squamous cells of undetermined significance/low-grade squamous intraepithelial lesions triage study (ALTS). Cancer. 2005;105 (5):253-62.

28. Clifford GM, Smith JS, Aguado T, Franceschi S. Comparison of HPV type distribution in high-grade cervical lesions and cervical cancer: a meta-analysis. Br J Cancer. 2003;89(1):101-5.

29. Day PM, Kines RC, Thompson CD, Jagu S, Roden RB, Lowy DR, Schiller JT. In vivo mechanisms of vaccine-induced protection against HPV infection. Cell Host Microbe. 2010;8(3):260-70.

30. Schiller JT, Day PM, Kines RC. Current understanding of the mechanism of HPV infection. Gynecol Oncol. 2010;118(1 Suppl):S12-7.

31. Frazer IH. Prevention of cervical cancer through papillomavirus vaccination. Nat Rev Immunol. 2004;4(1):46-54.

32. Villa LL, Costa RL, Petta CA, Andrade RP, Paavonen J, Iversen OE, Olsson SE, Høye J, Steinwall M, Riis-Johannessen G, Andersson-Ellstrom A, Elfgren K, Krogh G, Lehtinen M, Malm C, Tamms GM, Giacoletti K, Lupinacci L, Railkar R, Taddeo FJ, Bryan J, Esser MT, Sings HL, Saah AJ, Barr E. High sustained efficacy of a prophylactic quadrivalent human papillomavirus types 6/11/16/18 L1 virus-like particle vaccine through 5 years of follow-up. Br J Cancer. 2006;95(11):1459-66.

33. - Naud P, Roteli-Martins CM, De Carvalho N, Teixeira J, de Borba P, Sanchez N, Zahaf T, Geeraerts B, Descamps D. HPV-16/18 Vaccine: Sustained immunogencitiy and efficacy up to 9.4 years. Abstract oral presentation: O-18.04. 27th International Papillomavirus Conference. Berlin, Germany, 2011. This reference details the longest follow-up efficacy for Cervarix.

34. •- Wheeler CM, Castellsagué X, Garland SM, Szarewski A, Paavonen J, Naud P, Salmerón J, Chow SN, Apter D, Kitchener H, Teixeira JC, Skinner SR, Jaisamrarn U, Limson G, Romanowski B, Aoki FY, Schwarz TF, Poppe WA, Bosch FX, Harper DM, Huh W, Hardt K, Zahaf T, Descamps D, Struyf F, Dubin G, Lehtinen M; HPV PATRICIA Study Group. Cross-protective efficacy of HPV-16/18 AS04adjuvanted vaccine against cervical infection and precancer caused by non-vaccine oncogenic HPV types: 4-year end-of-study analysis of the randomised, double-blind PATRICIA trial. Lancet Oncol. 2012;13 (1):100-10. This article details the full oncogenic protection of Cervarix, which includes seven types in both the alpha-7 and alpha-9 species. Protection against seven oncogenic HPV types has led to the 93\% efficacy against all CIN 3 regardless of HPV type.

35. Stoler MH, Schiffman M, Atypical Squamous Cells of Undetermined Significance-Low-grade Squamous Intraepithelial Lesion Triage Study (ALTS) Group. Interobserver reproducibility of cervical cytologic and histologic interpretations: realistic estimates from the ASCUS-LSIL Triage Study. JAMA. 2001;285(11):1500-5.

36. Dauner JG, Pan Y, Hildesheim A, Kemp TJ, Porras C, Pinto LA. Development and application of a GuHCl-modified ELISA to measure the avidity of anti-HPV L1 VLP antibodies in vaccinated individuals. Mol Cell Probes. 2012;26(2):73-80.

37. Roteli-Martins C, Naud P, De Borba P, Teixeira J, De Carvalho N, Zahaf T, Sanchez N, Geeraerts B, Descamps D. Sustained immunogenicity and efficacy of the HPV-16/18 AS04-adjuvanted vaccine: up to 8.4 years of follow-up. Hum Vaccin Immunother. 2012;8(3).

38. Rowhani-Rahbar A, Mao C, Hughes JP, Alvarez FB, Bryan JT, Hawes SE, Weiss NS, Koutsky LA. Longer term efficacy of a prophylactic monovalent human papillomavirus type 16 vaccine. Vaccine. 2009;27(41):5612-9.

39. Olsson SE, Villa LL, Costa RL, Petta CA, Andrade RP, Malm C, Iversen OE, Høye J, Steinwall M, Riis-Johannessen G, AnderssonEllstrom A, Elfgren K, von Krogh G, Lehtinen M, Paavonen J, Tamms GM, Giacoletti K, Lupinacci L, Esser MT, Vuocolo SC, Saah AJ, Barr E. Induction of immune memory following administration of a prophylactic quadrivalent human papillomavirus (HPV) types 6/11/16/18 L1 virus-like particle (VLP) vaccine. Vaccine. 2007;25(26):4931-9.

40. Fairley CK, Hocking JS, Gurrin LC, Chen MY, Donovan B, Bradshaw CS. Rapid decline in presentations of genital warts after the implementation of a national quadrivalent human papillomavirus vaccination programme for young women. Sex Transm Infect. 2009;85(7):499-502.

41. http://www.fda.gov/downloads/BiologicsBloodVaccines/Vaccines/ ApprovedProducts/UCM190977.pdf. Accessed May 1, 2012.

42. Centers for Disease Control and Prevention (CDC). National, state, and local area vaccination coverage among adolescents aged 1317 years -- United States, 2009. MMWR Morb Mortal Wkly Rep. 2010 Aug 20;59(32):1018-23. Accessed at: http://www.cdc.gov/ $\mathrm{mmwr} /$ preview $/ \mathrm{mmwrhtml} / \mathrm{mm} 5932 \mathrm{a} 3 . \mathrm{htm}$ ? s cid=mm5932a3 w

43. •- Kreimer AR, Rodriguez AC, Hildesheim A, Herrero R, Porras C, Schiffman M, González P, Solomon D, Jiménez S, Schiller JT, Lowy DR, Quint W, Sherman ME, Schussler J, Wacholder S; CVT Vaccine Group. Proof-of-principle evaluation of the efficacy of fewer than three doses of a bivalent HPV16/18 vaccine. J Natl Cancer Inst. 2011;103(19):1444-51. This article shows that the Cervarix composition vaccine provides $100 \%$ efficacy in one dose. One-dose implementation is superior in all cost-effectiveness analyses for prevention of cervical cancer.

44. Barnabas RV, Laukkanen P, Koskela P, Kontula O, Lehtinen M, Garnett GP. Epidemiology of HPV 16 and cervical cancer in Finland and the potential impact of vaccination: mathematical modelling analyses. PLoS Med. 2006;3(5):e138.

45. Anttila A, Pukkala E, Söderman B, Kallio M, Nieminen P, Hakama M. Effect of organised screening on cervical cancer incidence and mortality in Finland, 1963-1995: Recent increase in cervical cancer incidence. Int J Cancer. 1999;83(1):59-65.

46. Ries LA, Eisner MP, Kosary CL, et al. SEER Cancer Statistics Review, 1973-1999. Bethesda: National Cancer Institute; 2002.

47. Harper DM, Williams KB. Prophylactic HPV vaccines: current knowledge of impact on gynecologic premalignancies. Discov Med. 2010;10(50):7-17.

48. Elbasha EH, Dasbach EJ, Insinga RP. Model for assessing human papillomavirus vaccination strategies. Emerg Infect Dis. 2007;13 (1):28-41.

49. Praditsitthikorn N, Teerawattananon Y, Tantivess S, Limwattananon $\mathrm{S}$, Riewpaiboon A, Chichareon S, Ieumwananonthachai $\mathrm{N}$, Tangcharoensathien V. Economic evaluation of policy options for prevention and control of cervical cancer in Thailand. PharmacoEconomics. 2011;29(9):781-806.

50. Villa LL, Costa RL, Petta CA, Andrade RP, Ault KA, Giuliano AR, Wheeler CM, Koutsky LA, Malm C, Lehtinen M, Skjeldestad 
FE, Olsson SE, Steinwall M, Brown DR, Kurman RJ, Ronnett BM, Stoler MH, Ferenczy A, Harper DM, Tamms GM, Yu J, Lupinacci L, Railkar R, Taddeo FJ, Jansen KU, Esser MT, Sings HL, Saah AJ, Barr E. Prophylactic quadrivalent human papillomavirus (types $6,11,16$, and 18) L1 virus-like particle vaccine in young women: a randomised double-blind placebo-controlled multicentre phase II efficacy trial. Lancet Oncol. 2005;6 (5):271-8.

51. Lehtinen M, Paavonen J, Wheeler CM, Jaisamrarn U, Garland SM, Castellsagué X, Skinner SR, Apter D, Naud P, Salmerón J, Chow SN, Kitchener H, Teixeira JC, Hedrick J, Limson G, Szarewski A, Romanowski B, Aoki FY, Schwarz TF, Poppe WA, De Carvalho NS, Germar MJ, Peters K, Mindel A, De Sutter P, Bosch FX, David MP, Descamps D, Struyf F, Dubin G, HPV PATRICIA
Study Group. Overall efficacy of HPV-16/18 AS04-adjuvanted vaccine against grade 3 or greater cervical intraepithelial neoplasia: 4-year end-of-study analysis of the randomised, double-blind PATRICIA trial. Lancet Oncol. 2012;13(1):89-99.

52. Muñoz N, Kjaer SK, Sigurdsson K, Iversen OE, Hernandez-Avila M, Wheeler CM, Perez G, Brown DR, Koutsky LA, Tay EH, Garcia PJ, Ault KA, Garland SM, Leodolter S, Olsson SE, Tang GW, Ferris DG, Paavonen J, Steben M, Bosch FX, Dillner J, Huh WK, Joura EA, Kurman RJ, Majewski S, Myers ER, Villa LL, Taddeo FJ, Roberts C, Tadesse A, Bryan JT, Lupinacci LC, Giacoletti KE, Sings HL, James MK, Hesley TM, Barr E, Haupt RM. Impact of human papillomavirus (HPV)-6/11/16/18 vaccine on all HPV-associated genital diseases in young women. J Natl Cancer Inst. 2010;102(5):325-39. 